\title{
Biogas Production Possibility from Aquaculture Waste
}

\author{
Sergejs Osipovs \\ Department of Applied Chemistry \\ Daugavpils University \\ Daugavpils, Latvia \\ sergejs.osipovs@du.lv \\ Jeḷena Kirilova \\ Department of Applied Chemistry \\ Daugavpils University \\ Daugavpils, Latvia \\ jelena.kirilova@du.lv
}

\author{
Aleksandrs Pučkins \\ Department of Applied Chemistry \\ Daugavpils University \\ Daugavpils, Latvia \\ aleksandrs.puckins@du.lv \\ Juris Soms \\ Department of Environmental \\ Science and Chemistry \\ Daugavpils University \\ Daugavpils, Latvia \\ juris.soms@du.lv
}

\author{
Mihails Pupinš \\ Department of Ecology \\ Daugavpils University \\ Daugavpils, Latvia \\ mihails.pupins@du.lv
}

\begin{abstract}
The research explores the possibilities of biogas extraction from aquaculture waste. Samples of fishfarming pool sludge were taken from a fish farm, which is located in the Krāslava district, Kalnieši rural municipality. Prior to experimental fermentation and extraction of biogas, samples were analyzed in order to determine their moisture and organic matter content (OMC). For purpose of increasing $\mathrm{OMC}$ available for fermentation, sludge was mixed with crushed reeds. Biogas was obtained from the samples at various ratios of sludge and reed residues. During the experiments, 3.81 liters of biogas were obtained from a mixture of fish-farming pool sludge and crushed reed at reed mass $100 \mathrm{~g}$. The results of experimental research indicate that aquaculture residues can be used to produce biogas.
\end{abstract}

Keywords - biogas, aquaculture, waste

\section{INTRODUCTION}

The current global energy supply depends on fossil fuels (oil, coal, natural gas). Fossil fuels are a nonrenewable resource and their reserves are declining very rapidly. In contrary to fossil fuels, biogas is a fully renewable resource because it is produced from biomass. The advantages of biogas also are obvious - (a) improving the country's energy balance, (b) making a major contribution to conserving natural resources and (c) improving the environmental situation and mitigation of global warming [1].
Another major environmental challenge for modern society is the growing amount of waste, including organic one. Controlled landfilling or deposition of organic waste is not a best practice, as environmental standards have now become much stricter [2].

Aquaculture is one of the fastest growing food industries in the world today. Growing global demand for food is driving the rapid development of aquaculture: from only $3.2 \%$ of total fisheries production in 1950, it has now reached $50 \%$, in response to limited natural resources and the rapid growth of the world's population [3].

As mentioned in Article 224 of the "Latvian Sustainable Development Strategy until 2030" on the use of biogas resources, "One of the potential resources for biogas production is biological waste. By developing biogas production, it can be used in the public transport sector, agriculture, as well as heat production" [4]. In 2016, the production volume of the aquaculture sector was 788 tons. One of the largest aquaculture companies at present is the joint-stock company "Nagli". Currently, Nagli Fisheries is the largest fish farm not only in Latvia but in the entire Baltics. It is a full-cycle aquaculture farm, which has its own carp and pike breeding material, where fish spawn is incubated, fry are farmed, and then fish production is being sent to market. The aquaculture facilities cover an area of about 2000 ha, which includes 
ponds, dams, land under the hatchery and workshops, and the Malta River reservoir, from which all fishing ponds are filled [5].

Potentially, Nagli Fisheries can produce up to 1,500 tons of aquaculture production per year. At the same time the amount of waste produced in the course of fish life cycle in this case will also be 1,500 tons per year. On the one hand, it is a very big problem - to dispose such amount of waste, but on the other hand - waste from fish breeding processes is a good raw material for biogas plants. For example, a biogas plant with an electrical capacity of 100 $\mathrm{KW}_{\mathrm{el}}$ requires about 6 tons of raw materials per day. This means that the "Nagli" aquaculture farm can practically provide a raw material biogas plant with an electrical capacity of $100 \mathrm{KW}_{\mathrm{el}}$, thus solving the problem of waste utilization and providing itself with electrical and thermal energy [6].

Fish processing companies also face waste disposal problems and energy shortages. In 2016, the number of fishery product processing companies was more than 100 , producing almost 100 tons of fish products. Waste from fish processing plants is also a good raw material for biogas plants [7].

Any organic substance can be used as a raw material for biogas production. It is useful to use existing and available biomass - manure, homogeneous by-products of food production, forest and wood processing waste, sewage sludge, municipal organic waste, straw, etc. The amount of biogas that can be obtained from different sources varies and is not a constant [8].

Substrates used for biogas production can be classified according to their origin, dry matter composition, methane yield and other criteria [9].

Substrates with a dry matter content of less than $20 \%$ are used for purposes of wet fermentation. This category includes animal slurry, sewage sludge, manure, as well as wet organic waste from the food industry (e.g. whey from milk products processing). Dry fermentation is used if the dry matter content of the substrates is at least $35 \%$ and it is typical for energy crops and silage [10]. Energy crops are represented by herbaceous plants (grass, maize, oilseed rape, etc.) grown directly for energy/biogas production and trees (willow, poplar, oak), although the trees require special pre-treatment for delignification [11].

Strict separation of wet and dry fermentation technologies is biologically misleading, as the microorganisms involved in the fermentation process need a liquid medium for growth and multiplication [12]. The classification of technologies depends not on the dry matter content of the individual substrates used, but on the dry matter content of the bioreactor. In wet fermentation technology, the dry matter content of the reactor is about $12 \%$ and the reactor content can usually be pumped by means of pumps because it is liquid. If the dry matter content of the reactor is increased to $15-16 \%$, the reactor content can no longer be pumped and this technology is called dry fermentation [13].

\section{MATERIALS AND METHODS}

\section{A. Biomass}

Aquaculture residues (sludge) from a fish farm located in the Krāslava district, Kalniešu rural municipality were selected as raw material for biogas production and research. Samples were taken from the farm's wastewater collectors. The reeds from Daugavpils Esplanāde park were used for increasing of OMC. The reeds were dried and divided into components: stems, leaves, flowers.

In order to successfully provide anaerobic fermentation processes, digestate from the biogas plant "Skaista", Daugava region, Skrudalienas parish was used.

\section{B. Laboratory scale bioreactor}

For the implementation of experimental research bioreactor EDF-5.4_2 manufactured by Biotehniskais centrs, Latvia was used. The aforementioned bioreactor has a compact, ergonomic and robust design fully customized for experimental research on biomethane production. Glass cylinder vessel is mounted between the upper lid and the metallic jacketed bottom. The design of the bioreactor is easy to maintain and apply basic operations and preparatory process, in particular, washing and autoclaving.

Gas mixing has been done using mass flow controllers Hamilton ARC $\mathrm{pH}$ and DO sensors. These sensors send 4$20 \mathrm{~mA}$ signals directly to process control system (PCS) and ensure at the same time information management via Bluetooth in smartphones or PC installed programs. This program generates a report about all calibration procedures, sterilization numbers, predicted service life. The sensors for identification and volumetric estimation of $\mathrm{O}_{2}, \mathrm{CO}_{2}, \mathrm{CH}_{4}$ are connected to PCS for off-gas analysis.

On-line/off-line data analysis and advanced process control possibilities were performed using PC implemented program (Matlab, Python) algorithms communicating to process control system (PCS and SCADA).

\section{Determination of sludge and reed moisture}

The sludge substance was mixed in a container with a metal spatula so that the moisture in the substrate was evenly distributed. Pieces of roots and other plant remains were removed from sludge by tweezers. A $10 \mathrm{~g}$ sample of substrate was weighed. The sample was placed in a humidity analyzer HB43-S with a drying temperature $105 \pm 2{ }^{\circ} \mathrm{C}$ [14]. The moisture content of the substrate was determined and a dry residue was obtained. The moisture of 3 samples was determined for the accuracy of one study. The resulting dry residue was further used to determine the OMC. Similar procedures were done by the reed. 


\section{Determination of sludge and reed organic matter content}

The empty crucibles were placed in a muffle furnace where they were heated to $550 \pm 10^{\circ} \mathrm{C}$ for at least 60 minutes. Then the crucibles were removed from furnace and placed on a heat-resistant surface for 5-10 minutes, subsequently after a while the crucibles were left to cool in a desiccator. The cooled crucible was weighed to the nearest $0.1 \mathrm{mg}$ on an analytical balance and weigh 1 to 2 $\mathrm{g}$ of the test sample was put into the crucible. The test sample was heated in a muffle furnace for two hours at $800 \pm 10^{\circ} \mathrm{C}$; after that placed in a cool desiccator. This procedure of heating and weighing was repeated to constant weight. The organic matter content was calculated as a percentage of the dry residue [15]. Similar procedures were done by the reed.

\section{E. Preparation of the mixture for biogas production}

The experiment was repeated three times. To the prepared 1,200 $\mathrm{g}$ of aquaculture sludge was added $50 \mathrm{~g}$, $100 \mathrm{~g}$, and $150 \mathrm{~g}$ of crushed reed powder and mixed thoroughly. The prepared mixture was thoroughly immersed in the reactor vessel and $300 \mathrm{~mL}$ of bog water was added, mixed thoroughly with a metal spatula. 1,000 $\mathrm{g}$ of digestat was added and then firmly sealed with a bioreactor lid. The appropriate temperature mode and agitator rotation speed are selected and connected to the bioprocess controller.

\section{F. Selected parametrs of the bioprocess controller}

The following were used in the bioprocess controller to perform the work:

- $\quad 40^{\circ} \mathrm{C}$ temperature mode;

- Agitator rotation speed interval $50 \mathrm{rpm}$;

- Foam level sensors.

A computer with SCADA software was connected to the bioreactor, which recorded the volume and composition analysis of the released biogas.

\section{RESULTS AND DISCUSSION}

\section{A. Determination of sludge and reed moisture and} organic matter content

The obtained moisture results of sludge samples are valid for biogas production, as the dry residue in substrate samples is about $15 \%$ (see Tab. 1). The results are in line with the type of wet fermentation, which is similar to the other potential biogas technology [16].

TABLE 1 SLUDGE AND REED MOISTURE AND ORGANIC MATTER CONTENT

\begin{tabular}{|l|c|c|}
\hline \multicolumn{1}{|c|}{ Biomass } & Moisture, \% & $\begin{array}{c}\text { Organic matter } \\
\text { content (from dry } \\
\text { matter), \% }\end{array}$ \\
\hline Sludge & $85.63 \pm 0.32$ & $29.49 \pm 0.92$ \\
\hline
\end{tabular}

\begin{tabular}{|l|l|l|}
\hline Reed & $0.99 \pm 0.17$ & $95.88 \pm 1.16$ \\
\hline
\end{tabular}

The amount of organic matter obtained from sludge samples is about $29 \%$, which indicates a high content of inorganic substances in the substrate. In order to obtain more biogas yield in the study, a relatively larger amount of aquaculture sludge must be placed into the bioreactor, with the addition of another type of substrate in which the percentage of organic matter is about $90 \%$ or more.

The amount of organic matter obtained from reed samples is about $96 \%$, which indicates a high content of organic matter, so it is advantageous to add it to the fishfarming pool sludge in a certain ratio. For experimental research the three mixtures were used to produce biogas.

\section{B. Biogas production}

During each experiment, the released volume of biogas and the gas composition in the obtained biogas were studied with the research software SCADA (Supervisory control and data acquisition).

The Fig. 1, Fig. 2, and Fig. 3 shows the trend in biogas volume release over 60 days at added reed $50 \mathrm{~g}, 100 \mathrm{~g}$, and $150 \mathrm{~g}$ respectively.

Of the total biogas produced during the fermentation period (60 days), 95\% was produced within the period from the $10^{\text {th }}$ to the $55^{\text {th }}$ day. This regularity was observed for all three types of sludge and reed proportions (see Fig. 1-3). The optimal retention time is about 33 and 35 days at added reed $50 \mathrm{~g}, 36$ days at added reed $100 \mathrm{~g}$, and 3536 days for at added reed $150 \mathrm{~g}$.

The total volume of biogas, produced during the fermentation period, is about 2.84 liters from sample with added reed $50 \mathrm{~g}, 3.81$ liters from sample with added reed $100 \mathrm{~g}$, and 3.28 liters from sample with added reed $150 \mathrm{~g}$ (see Fig. 1-3).

The Fig. 1, Fig. 2, and Fig. 3 shows the trend in biogas volume release over 60 days at added reed $50 \mathrm{~g}, 100 \mathrm{~g}$, and $150 \mathrm{~g}$ respectively.

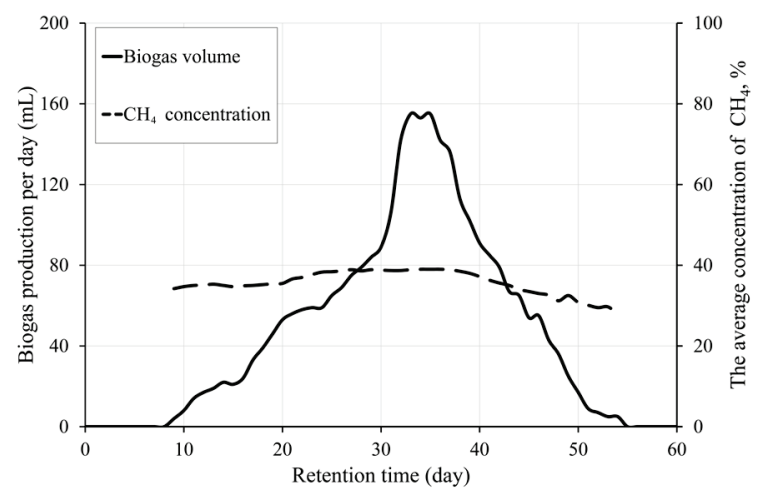

Fig. 1. Trend in biogas volume and proportion of methane in biogas release over 60 days at added reed $50 \mathrm{~g}$. 


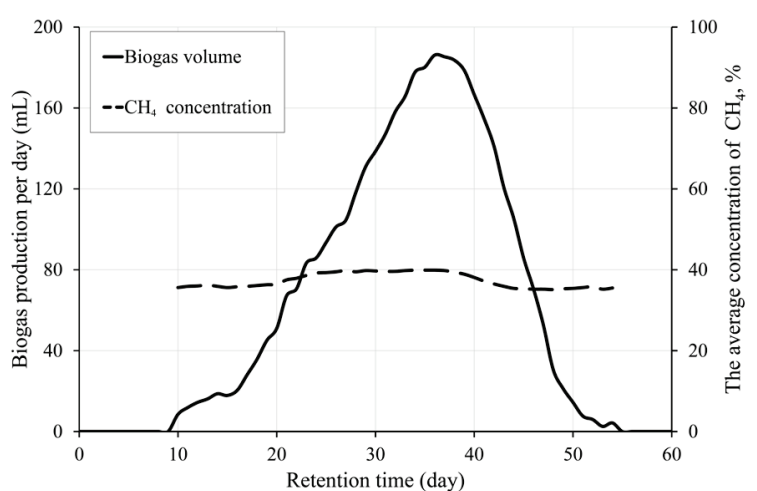

Fig. 2. Trend in biogas volume and proportion of methane in biogas release over 60 days at added reed $100 \mathrm{~g}$.

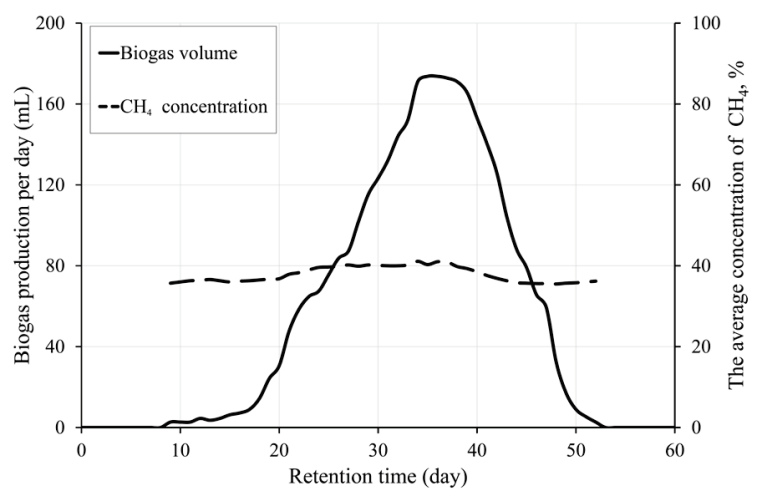

Fig. 3. Trend in biogas volume and proportion of methane in biogas release over 60 days at added reed $150 \mathrm{~g}$.

The average concentration of methane in biogas is $35.6 \%$, carbon dioxide is $63.3 \%$, other gases are $1.1 \%$ from the sample with added $50 \mathrm{~g}$ of reed, methane is $37.3 \%$, carbon dioxide is $61.8 \%$, other gases are $0.9 \%$ from the sample with added $100 \mathrm{~g}$ of reed, and methane $37.8 \%$, carbon dioxide $-61.0 \%$, other gases $1.2 \%$ from the sample with added $150 \mathrm{~g}$ of reed (see Fig. 1-3).

\section{CONCLUSIONS}

The studies of biogas yield during the bio-fermentation process depending on the effect of the proportion of biomass components - sludge and reed indicate that the result was not so unambiguous.

During the experiments, 2.84 liters of biogas were obtained from a mixture of aquaculture sludge and crushed reed at added reed $50 \mathrm{~g}, 3.81$ liters at added reed $100 \mathrm{~g}$, and 3.28 liters at added reed $150 \mathrm{~g}$. From this, we cannot conclude that if the organic matter content in sludge is higher, the biogas yield would increase during the process.

However, the proportion of methane in biogas increased during the fermentation process, if the organic matter content in sludge were higher.

Accordingly, it is difficult to decide which ratio of sludge and reed in biomass is optimal - on the one hand adding $100 \mathrm{~g}$ of reed to the aquaculture sludge resulted in a larger volume of biogas, on another hand - adding 150 $\mathrm{g}$ of reed to the aquaculture sludge resulted in the highest percentage of methane in biogas. Hence it highlights the necessity of further research.

\section{ACKNOWLEDGMENTS}

This research was supported within the Daugavpils University internal research project competition (project "Biogas production possibility from aquaculture waste"; Nr. 14-95/2021/20).

\section{REFERENCES}

[1] S. Achinas, V. Achinas and G. J. W. Euverink, "A Technological Overview of Biogas Production from Biowaste" Engineering, vol. 79, pp. 299-307, June 2017. Available: ScienceDirect, https://www.sciencedirect.com/ [Accessed March 30, 2021], https://doi.org/10.1016/J.ENG.2017.03.002

[2] K. Paritosh, S. K. Kushwaha, M. Yadav, N. Pareek, A. Chawade and V. Vivekanand, "Food Waste to Energy: An Overview of Sustainable Approaches for Food Waste Management and Nutrient Recycling" BioMed Research International, vol. 2017, pp. 1-19, February 2017. Available: Hindawi, https://www.hindawi.com/ [Accessed March 30, 2021], https://doi.org/10.1155/2017/2370927

[3] A. Ahmad, S. R. S. Abdullah, H. A. Hasan, A. R. Othman and N. I. Ismail, "Aquaculture industry: Supply and demand, best practices, effluent and its current issues and treatment technology" Journal of Environmental Management, vol. 287, 112271, June 2021. Available: ScienceDirect, https://www.sciencedirect.com/ [Accessed March 30, 2021], https://doi.org/10.1016/j.jenvman.2021.112271

[4] “Latvijas ilgtspējīgas attīstības stratēǵija līdz 2030. gadam”, 2010. [Online]. Available: https://www.pkc.gov.lv/sites/default/files/inlinefiles/Latvija_2030_6.pdf [Accessed: March 30, 2021].

[5] D. Blumberga, L. Balode, K. Bumbiere, Z. Indzere, E.Kudurs, K. Spalviņš, A. Vēciṇa and A. Tamane, "Zivju apstrādes efektivitātes ceḷvedis". Rīga: RTU Izdevniecība, 2021.

[6] "Biogāzes ražošanas attīstības iespējas Cēsu, Daugavpils, Jēkabpils, Madonas, Gulbenes un Valkas rajonos: atskaites ziņojums", 2008. [Online]. Available: http://petijumi.mk.gov.lv/sites/default/files/file/RAPLM Biogaze s_razosanas iespejas.doc [Accessed: March 30, 2021].

[7] C. E. Manyi-Loh, S. N. Mamphweli, E. L. Meyer, A. I. Okoh, G. Makaka and M. Simon, "Microbial Anaerobic Digestion (BioDigesters) as an Approach to the Decontamination of Animal Wastes in Pollution Control and the Generation of Renewable Energy" International journal of environmental research and public health, vol. 10, pp. 4390-4417, September 2013. Available: MDPI, https://www.mdpi.com/ [Accessed March 30, 2021], https://doi.org/10.3390/ijerph10094390

[8] C. Zhang, H. Su, J. Baeyens and T. Tan, "Reviewing the anaerobic digestion of food waste for biogas production" Renewable and Sustainable Energy Reviews, vol. 38, pp. 383-392, October 2014. Available: ScienceDirect, https://www.sciencedirect.com/ [Accessed $\quad$ March $\frac{30,}{2021],}$ https://doi.org/10.1016/j.rser.2014.05.038

[9] K. Zhou, S. Chaemchuen and F. Verpoort, "Alternative materials in technologies for Biogas upgrading via $\mathrm{CO}_{2}$ capture" Renewable and Sustainable Energy Reviews, vol. 79, pp. 1414-1441, November 2017. Available: ScienceDirect, https://www.sciencedirect.com/ [Accessed March 30, 2021], https://doi.org/10.1016/j.rser.2017.05.198

[10] K. Hagos, J. Zong, D. Li, C. Liu and X. Lu, "Anaerobic codigestion process for biogas production: Progress, challenges and perspectives" Renewable and Sustainable Energy Reviews, vol. 76, pp. 1485-1496, September 2017. Available: ScienceDirect, https://www.sciencedirect.com/ [Accessed March 30, 2021], https://doi.org/10.1016/j.rser.2016.11.184

[11] M. Zhou, B. Yan, J. W. C. Wong and Y. Zhang, "Enhanced volatile fatty acids production from anaerobic fermentation of food waste: 
A mini-review focusing on acidogenic metabolic pathways" Bioresource Technology, vol. 248 (Part A), pp. 68-78, January 2018. Available: ScienceDirect, https://www.sciencedirect.com/

[Accessed

$$
\text { March }
$$

2021], https://doi.org/10.1016/j.biortech.2017.06.121

[12] M. Westerholm, S. Isaksson, O. K. Lindsjö and A. Schnürer, "Microbial community adaptability to altered temperature conditions determines the potential for process optimisation in biogas production" Applied Energy, vol. 226, pp. 838-848, September 2018. Available: ScienceDirect, https://www.sciencedirect.com/ [Accessed March 30, 2021], https://doi.org/10.1016/j.apenergy.2018.06.045

[13] J. N. Meegoda, B. Li, K. Patel and L. B. Wang, "A Review of the Processes, Parameters, and Optimization of Anaerobic Digestion" International journal of environmental research and public health, vol. 15, 2224, October 2018. Available: MDPI, https://www.mdpi.com/ [Accessed March 30, 2021], https://doi.org/10.3390/ijerph15102224

[14] S. K. Pramanik, F. B. Suja, S.M. Zain and B.K. Pramanik, "The anaerobic digestion process of biogas production from food waste:
Prospects and constraints" Bioresource Technology Reports, vol. 8, 100310, December 2019. Available: ScienceDirect, https://www.sciencedirect.com/ [Accessed: March 30, 2021], https://doi.org/10.1016/j.biteb.2019.100310

[15] S. Achinas and G. J. W. Euverink, "Theoretical analysis of biogas potential prediction from agricultural waste" Resource-Efficient Technologies, vol. 2, pp. 143-147, September 2016. Available: ScienceDirect, https://www.sciencedirect.com/ [Accessed: March 30, 2021], https://doi.org/10.1016/j.reffit.2016.08.001

[16] J. Kainthola, A. S. Kalamdhad and V. V. Goud, "A review on enhanced biogas production from anaerobic digestion of lignocellulosic biomass by different enhancement techniques" Process Biochemistry, vol. 84, pp. 81-90, September 2019. Available: ScienceDirect, https://www.sciencedirect.com/ [Accessed: March 30,2021 , https://doi.org/10.1016/i.procbio.2019.05.023 